\title{
Psychotria viridis: Chemical constituents from leaves and biological properties
}

\author{
DÉBORA B.S. SOARES ${ }^{1}$, LUCIENIR P. DUARTE ${ }^{1}$, ANDRÉ D. CAVALCANTI ${ }^{2}$, FERNANDO C. SILVA ${ }^{3}$, \\ ARIADNE D. BRAGA ${ }^{4}$, MIRIAM T.P. LOPES ${ }^{4}$, JACQUELINE A. TAKAHASHI ${ }^{1}$ and SIDNEY A. VIEIRA-FILHO ${ }^{5}$ \\ ${ }^{1}$ Departamento de Química, Instituto de Ciências Exatas, Universidade Federal de Minas \\ Gerais, Avenida Antônio Carlos 6627, 31270-901 Belo Horizonte, MG, Brazil \\ ${ }^{2}$ Setor Técnico-Científico do Departamento de Polícia Federal de Minas Gerais, Rua \\ Nascimento Gurgel, 30, 30441-170 Belo Horizonte, MG, Brazil \\ ${ }^{3}$ Universidade do Estado de Minas Gerais, Unidade de Divinópolis, Avenida Paraná, 3001, 35501-170 Divinópolis, MG, Brazil \\ ${ }^{4}$ Departamento de Farmacologia, ICB, Universidade Federal de Minas Gerais, Av. \\ Antônio Carlos, 6627, Pampulha, 31270-901 Belo Horizonte, MG, Brazil \\ ${ }^{5}$ Departamento de Farmácia, Escola de Farmácia, Universidade Federal de Ouro Preto, \\ Campus Universitário, 35400-000 Ouro Preto, Minas Gerais, Brazil
}

Manuscript received on June 27, 2016; accepted for publication on October 14, 2016

\begin{abstract}
The phytochemical study of hexane, chloroform and methanol extracts from leaves of Psychotria viridis resulted in the identification of: the pentacyclic triterpenes, ursolic and oleanolic acid; the steroids, 24 -methylene-cycloartanol, stigmasterol and $\beta$-sitosterol; the glycosylated steroids 3 - $O$ - $\beta$-D-glucosyl- $\beta$ sitosterol and 3-O- $\beta$-D-glucosyl-stigmasterol; a polyunsaturated triterpene, squalene; the esters of glycerol, 1-palmitoylglycerol and triacylglycerol; a mixture of long chain hydrocarbons; the aldehyde nonacosanal; the long chain fat acids hentriacontanoic, hexadecanoic and heptadenoic acid; the ester methyl heptadecanoate; the 4-methyl-epi-quinate and two indole alkaloids, $N, N$-dimethyltryptamine (DMT) and $N$-methyltryptamine. The chemical structures were determined by means of spectroscopic (IR, ${ }^{1} \mathrm{H}$ and ${ }^{13} \mathrm{C}$ NMR, HSQC, HMBC and NOESY) and spectrometric (CG-MS and LCMS-ESI-ITTOF) methods. The study of biologic properties of $P$. viridis consisted in the evaluation of the acetylcholinesterase inhibition and cytotoxic activities. The hexane, chloroform, ethyl acetate and methanol extracts, the substances 24-methylene-cycloartanol, DMT and a mixture of 3-O- $\beta$-D-glucosyl- $\beta$-sitosterol and 3-O- $\beta$-D-glucosyl-stigmasterol showed cholinesterase inhibiting activity. This activity induced by chloroform and ethyl acetate extracts was higher than $90 \%$. The methanol and ethyl acetate extracts inhibit the growth and/or induce the death of the tumor cells strains B16F10 and 4T1, without damaging the integrity of the normal cells BHK and CHO. DMT also demonstrated a marked activity against tumor cell strains B16F10 and 4T1.
\end{abstract}

Key words: Psychotria viridis, Rubiaceae, $N, N$-dimethyltryptamine, B16F10, 4T1 tumor cells.

\section{INTRODUCTION}

Brazil has a large plant genetic diversity, with more than 55,000 species cataloged (Nodari and Guerra

Correspondence to: Fernando César Silva

E-mail: fernando.cesar@uemg.br
1999, Veiga 2008). In the Amazon region, the use of medicinal plants has its bases in indigenous practice (Labate 2011). Many of these plants are also used in religious rituals. This practice originated from the great cultural influence of the ancient peoples of the 
Amazon, which was mixed with African traditions and European culture brought by the colonizers (Almeida 2011). Ritualistic plants become sacred when their use in ritual gives them a sacred value, to be legitimized through rites of a given belief model, philosophy or kind of thinking (Camargo 2006). These plants eliminate fatigue and insomnia, relieve the feeling of hunger, stimulate or cancel sexuality, induce depression or euphoria, provoke visions and fantastic predictions. In general, they are ingested orally in nature or prepared or enters the body by means of the oral route by inhalation of its fumes, or smelled; or topically applied to healthy or scarified skin. As a result, the use of such plants or its derivatives has been popularized worldwide, both for religious purposes, or not (Camargo 2007). The effect of these substances is confused with religious mysticism of the Indians and the wisdom of healers, shamans and "pajé", which usually play a dual role of religious guide and medicine doctor in your tribe. Thus, it is difficult to distinguish between the pharmacological actions of these preparations and their placebo effects on phenomenological healings that occur in rituals (Callaway et al. 1994, Callaway and Grob 1998). Most ritual plants used in healing ceremonies in shamanism, umbanda and other rituals, acts in the CNS in order to facilitate communication with spirit guides (Corrêa et al. 1998, Camargo 2006, 2007). Several studies have been conducted to discover new compounds that reach pharmacological targets in the CNS. The harmin represents an example of $\beta$-carboline alkaloid isolated from Banisteriopsis caapi (Malpighiaceae), which is a component of ayahuasca (yagé, hoasca, daime or caapi), a ritualistic beverage used in Brazil, Bolivia, Equador and Peru (Callaway and Grob 1998). This alkaloid acts on CNS inhibiting the monoamino-oxidase (MAO) (Breakefield et al. 1976, Pires et al. 2010). Inhibitors of MAO induce an enhancement of the amine concentration in brain, mainly dopamine, noradrenalin and serotonin, generating a state of excitement, euphoria, increased psychomotor activity (antidepressant), and others (Farzin and Mansouri 2006). It is also observed hallucinogenic effect attributed to structural similarity with endogenous amines, such as tryptamine and serotonin (Fortunato 2009). Other examples of ritualistic plants that alter the SNC physiology include Lophophora williamsii (Lem. ex SalmDyck J.M. Coult.) (Peiote) used in México and Central America, the Mimosa hostiles Benth (Jurema), in Northeast of Brazil, the Tabernanthe iboga Baill (Iboga) in Africa and Peganum harmala L. (Pégano) in the Middle East (Teixeira et al. 2008).

Among the species of plants with potential medicinal property are several members of the family Rubiaceae, due to the large number of substances with potential biological activity, including compounds belonging to different chemical classes, such as alkaloids and anthraquinones (Chan-Blanco et al. 2006, Delprete and Jardim 2012). This family is constituted by the subfamilies Ixoroideae, Rubioideae, Cinchonoideae Raf. And Antirheoideae Raf., covering aproximatley 650 genera and 13,000 species (Lima 2011). In South America, there are $30 \%$ of all species of the Rubiaceae family, which exceeds in number of species, all regions of the Earth, being then in South Asia and Africa. In Brazil, Rubiaceae family is represented by about 2,000 species distributed among 110 genera (Delprete and Jardim 2012). In the most important Brazilian ecosystems such as the Amazon and Cerrado regions and Atlantic Forest, species of this family are the form of trees, shrubs, subshrubs or perennial or annual herbs, and lianas and epiphytes. The species of Rubiaceae have great diversity of secondary metabolites such as indole alkaloids, tannins, triterpenes, saponins, steroids and flavonoids (Lima 2011). This justifies its use in traditional medicine and in the manufacture of herbal medicinal products. An example is the cat's claw "unha de gato", Uncaria tomentosa (Willd. 
ex Schult.) DC, whose extract obtained from its roots is indicated for the treatment of rheumatism and arthritis (Moraes 2013). The subfamily Rubioideae is considered as the second source of highest concentration of alkaloids (Delprete and Jardim 2012) belonging to different classes, such as isoquinoline (44 identified constituents) quinoline (70 compounds) and indole (391 constituents) (Cordell et al. 2001).

The species of subfamily Rubioideae are divided into 15 tribes, the largest being the Psychotrieae, comprised of approximately 50 genera widely distributed throughout the tropical zone (Libot et al. 1987). The Psychotria genus was first described by Linneaus in 1759, and actually is considered as one of the largest plant genera with flowers. Nowadays, in this genus are included about 1000 species (Steyermark 1974, Nepokroeff et al. 1999). According to morphological characteristics and geographical distribution, it is divided into three subgeneras: Psychotria (pantropical), Heteropsychotria (including neotropical species of Psychotria) and Tetramerae which includes species of Africa and Madagascar (Faria 2009). Different species of the genus Psychotria are used in traditional medicine for the treatment of disorders of the female reproductive tract and as an aid to relieve symptoms that occur pre- and postpartum, and also to treat diseases of the bronchi and gastrointestinal disorders (Lima 2011). Topically, in the form of poultices or baths species of this genus are used to treat skin disorders, "tumors", ulcer, ocular disorders, to relieve fever, headaches and earache (Faria 2009). Bioactive materials are obtained from various species of Psychotria such as extracts of $P$. microlabastra (Khan et al. 2001) and $P$. capensis that showed antibiotic activity, of $P$. serpens that presented antiviral properties, of $P$. hawaiiensis (Locher et al. 1995) and P. insularum, to which antiviral, antifungal and anti-inflammatory properties were attributed (Dunstan et al. 1997).
Psychotria viridis (Rubiaceae) is a species used in the preparation of ayahuasca drink, in association with Banisteriopsis caapi Morton (Callaway and Grob 1998). The Shamans and Healers of the Amazonia first used the drink. They practiced traditional medicine based on plant extracts (Luna 1986). The use of $N, N$-dimethyltryptamine (DMT), one constituent of this drink, due to its psychotropic effect is banned in Brazil (ANVISA, Portaria, 344/98). However, in August 2006, was enacted in Brazil the law $n^{0} 11.343$, which allows its use in "religious rituals" as long as authorized by the State. This law is in accordance with the Vienna Convention, promoted by the United Nations in 1971 with the aim of establishing the rules on the use of "psychotropic substances" (Groisman 2013). The release of scientific research and ritualistic use of ayahuasca is regulated in Brazil, through Resolution $n^{0} 1 / 2010$ of the National Council for Drug Policy (Garrido and Sabino 2009).

$P$. viridis is commonly known as "chacrona" or "chacruna" and is morphologically similar to other species of the genus (Blackledge and Taylor 2003) and was firstly described in 1779 by Ruiz and Pavón (Aranha et al. 1991). It is represented by shrubs and grows naturally in flat and humid forest areas from the northern region of Central America to Central South America. It is most commonly found in the Amazon region of Peru and northern Bolivia (Blackledge and Taylor 2003).

Herein it is described a phytochemical study of $P$. viridis aiming the isolation of bioactive secondary metabolites, followed by the structural identification by means of spectroscopic methods, and evaluate the biological properties of extracts and constituents present in its leaves.

\section{MATERIALS AND METHODS}

\section{PLANT MATERIAL}

Leaves of $P$. viridis were collected in the morning, at the extensive culture of the nucleus of "União do 
Vegetal" located at Lagoa da Prata municipality, Minas Gerais. P. viridis cultivated in this region is originally from the State of Rondonia, Brazil, which is located at the center of Amazon region. The collected plant material was dried in a forced ventilation oven at $40{ }^{\circ} \mathrm{C}$ for two days.

GENERAL PROCEDURES

Silica gel 60 (Merck) [7g:15mL water] $0.25 \mathrm{~mm}$ thickness was used for thin layer chromatography (TLC) and $0.50 \mathrm{~mm}$ for preparative assays (PTLC), after dried at $100{ }^{\circ} \mathrm{C} / 30$ minutes. The plates were revealed by means of UV light irradiation on CHROMATO-UVE, Ultra-Violet Products, Inc., and after treatment with chromogenic reactants. Chromatographic columns (CC) were performed on silica gel 60 (70-230 Mesh), with ratio sample/ stationary phase of 1:40 w/w. The elution solvents were analytical grade pure or in mixtures of enhanced polarity. Medium Pressure Column Chromatography (MPLC) was performed on Isolera-One, Biotage ${ }^{\mathrm{TM}}$, equipped with UV detector (UV1 $254 \mathrm{~nm}$, UV2 $280 \mathrm{~nm}$ ) and SNAP ${ }^{\mathrm{TM}} 100 \mathrm{~g}$ column, with $50 \mathrm{~mL} / \mathrm{min}$ mobile phase. The melting point of isolated compounds was determined using a Microquímica MQAPF-302 apparatus. Fourier transform infrared (FTIR) spectra were obtained for solid samples dissolved in $\mathrm{KBr}[1 \%$ (w/w)], using Spectrum One Perkin Elmer spectrometer. The 1D/2D NMR spectra were performed on Bruker AVANCE DPX-200 or DRX-400 spectrometers. Deuterated solvents are indicated for each analyze. Chemical shift assignments were recorded in ppm $(\delta)$ using tetramethylsilane (TMS) as internal reference $\left(\delta_{\mathrm{H}}=\delta_{\mathrm{C}}=0\right)$. The coupling constants $(J)$ were registered in Hertz (Hz). Gas chromatography coupled with mass spectrometry (CG-MS) was carried out on AGILENT 7890A GC FOR 5975 series MSD, equipped with HP 5MS (30 $\mathrm{m} \times 0,25$ $\mathrm{mm} \times 0,25 \mu \mathrm{m})$ column. Helium $(1.4 \mathrm{~mL} / \mathrm{min})$ was used as carrier gas. A Shimadzu LC-20AD apparatus coupled to mass spectrometer Shimadzu IT-TOF, hybrid with analyzers type ion trap and TOF in sequence (LCMS-ESI-IT-TOF) was also applied in some analysis of constituents from leaves of $P$. viridis.

\section{EXTRACTION AND ISOLATION OF COMPOUNDS}

The air-dried leaf (362.4 g) of $P$. viridis was sequentially extracted with hexane, chloroform, ethyl acetate, and methanol through maceration at room temperature. Each extractor solvent was recovered using IKA ${ }^{\circledR}$ Rotary Evaporator RV 10, and the residual solvent was evaporated to dryness under vacuum, producing the EHF, ECF, EAcF and EMeF extracts.

The hexane extract (EHF, $4.3 \mathrm{~g}$ ) was separated in two aliquots: A (2.2 g) and B (2.1 g), due to the maximum capacity of sample used in the chromatographic column (CC). The samples A and $\mathrm{B}$ were chromatographed separately using the equipment Isolera-One and eluted with hexane, chloroform and methanol pure or in mixtures of increasing polarity. The fractions collected from A and B were subjected to TLC and grouped in five groups in accordance with the profile similarity. All groups were subjected to silica gel CC and eluted with a hexane, ethyl acetate and methanol pure or in mixtures of increasing polarity. The group 5 was also submitted to PTLC. The groups 1-5 affording the compounds (1; a mixture of long chain hydrocarbons) (26.8 mg; eluted with hexane), (2; 24-methylene-cycloartenol) (16.2 mg; eluted hexane/ethyl acetate 97:3), (3; squalene) (4.2 mg; eluted hexane/ethyl acetate 93:7), (4 and 5; a mixture of $\beta$-sitosterol and stigmasterol, respectively) (20.6 mg; eluted with hexane/ethyl acetate 88:12), and (6; triacylglycerol) (16.7 mg; eluted with hexane/ ethyl acetate 86:14), respectively.

The chloroform extract (ECF, $4.1 \mathrm{~g}$ ) was subjected to silica gel CC using as eluent chloroform, ethyl acetate and methanol pure or in 
mixtures of increasing polarity. The fractions were grouped by means of TLC, furnishing six groups. The group 1 was submitted to successive silica gel CC affording the compound 7 (nonacosanal) (10.6 mg; eluted with hexane/chloroform 75:25). The group 2 was dissolved in acetone, furnishing compound 8 (nonacosanol) (25.4 $\mathrm{mg}$ ) as a precipitated. The group 3 was dissolved in acetone, furnishing compound 9 (hentriacontanoic acid) $(9.0 \mathrm{mg})$ as a precipitated, and the filtrated after solvent evaporation was submitted to silica gel CC, affording compound $\mathbf{1 0}$ (hexadecanoic acid) (3.3 mg; eluted with hexane/ethyl acetate 90:10). The group 4 was submitted to silica gel $\mathrm{CC}$, affording compound 11 (heptadenoic acid) (7.8 mg; eluted with hexane/ethyl acetate 80:20). The group 5 was subjected to successive silica gel CC, affording a mixture (4.5 mg; eluted with hexane/ethyl acetate 70:30) of compounds $\mathbf{1 2}$ and $\mathbf{1 3}$, respectively identified as ursolic acid and oleanolic acid. The group 6 was submitted to silica gel, affording compound 14 (1-palmitoylglycerol) ( $5.5 \mathrm{mg}$; eluted with hexane/ethyl acetate 50:50).

By means of TLC the ethyl acetate extract $(\mathrm{EAcF})$ was characterized as complex mixture, and due to the small quantity obtained $(<50 \mathrm{mg})$, it was not subjected to phytochemical processes.

The methanol extract (EMeF, $43.6 \mathrm{~g}$ ) was separated in two aliquots, A (23.5 g) and B (20.1 g). Aliquot A was subjected to acid-base extraction according to methodology suggested by Matos (1988), and Wagner and Bladt (1996), providing four fractions. The fraction 1 was subjected to silica gel CC, affording a solid mixture $(29.1 \mathrm{mg}$; eluted with chloroform/methanol 70:30, and purified by acetone) constituted by compounds $\mathbf{1 5}$ and $\mathbf{1 6}$, respectively identified as $3-O-\beta$-D-glucosyl- $\beta$ sitosterol and 3-O- $\beta$-D-glucosyl-stigmasterol. The fractions 2 and 3 were separately subjected to silica gel CC, and purified by means of PTLC, affording the compound 17 ( $N, N$-dimethyltryptamine) (52.9 mg; eluted with chloroform/methanol 97:3, under atmosphere of ammonium hydroxide). The fraction 4 was submitted to successive silica gel CC, affording a solid mixture $(15.7 \mathrm{mg}$; eluted with chloroform/methanol 97:3 with atmosphere of ammonium hydroxide) constituted by compounds $\mathbf{1 7}$ and $\mathbf{1 8}$, respectively identified as $N, N$-dimethyltryptamine and $N$-methyltryptamine. The aliquote B was submitted to silica gel CC, eluted with a chloroform, methanol and ammonium hydroxide pure or in mixtures of increasing polarity. The fractions were grouped by means of TLC, furnishing two groups. Group 1 was dissolved in acetone, furnishing compound 19, (methyl 4-epi-quinate) (11.2 $\mathrm{mg}$ ) as a solid material. The group 2 was submitted to silica gel CC followed by PTLC, affording the compounds 20, (methyl heptadecanoate) (41.4 mg; eluted with chloroform), 17, ( $N, N$-dimethyltryptamine) (19.1 mg; eluted with chloroform/methanol 97:3 under atmosphere of ammonium hydroxide), and 18, ( $N$-methyltryptamine) $(8.5 \mathrm{mg}$; eluted with chloroform/methanol 97:3 under atmosphere of ammonium hydroxide).

\section{BIOLOGICAL ASSAYS}

\section{Acetylcholinesterase inhibition assay}

The acetylcholinesterase (AChE) inhibition property of substances isolated from $P$. viridis was performed in 96 wells microtiter plate using Ellman's spectrophotometric method modified by Rhee et al. (2001). Thus, buffer A (50 $\mathrm{mM}$ Tris- $\mathrm{HCl}, \mathrm{pH} 8$, containing $0.1 \mathrm{M} \mathrm{NaCl}$ and $\left.0.02 \mathrm{M} \mathrm{MgCl}_{2} \cdot 6 \mathrm{H}_{2} \mathrm{O}\right), \mathrm{B}(50 \mathrm{mM}$ Tris- $\mathrm{HCl}, \mathrm{pH}$, containing $0.1 \%$ bovine serum albumin), and $\mathrm{C}$ (50 $\mathrm{mM}$ Tris- $\mathrm{HCl}, \mathrm{pH} 8$ ) were prepared to the in vitro AChE inhibitory activity assays. The volumes of $25 \mu \mathrm{L}$ of acetylcholine iodide (15 $\mathrm{mM}$ in water), $125 \mu \mathrm{L}$ of Ellman's reagent [5,5-dithiobis-(2nitrobenzoic acid)] ( $3 \mathrm{mM}$ in buffer A), $50 \mu \mathrm{L}$ of buffer $\mathrm{B}$, and $25 \mu \mathrm{L}$ of sample $(10 \mathrm{mg} / \mathrm{mL}$ in $\mathrm{MeOH}$ 
diluted by 10 times with buffer $\mathrm{C}$, providing a final concentration of $1.0 \mathrm{mg} / \mathrm{mL}$ ) were added into each well of a 96-well microtiter plate. Instead of adding the sample solution, a volume of $25 \mu \mathrm{L}$ of buffer $\mathrm{C}$ was used to prepare the blank sample. The positive control was prepared under same conditions. Each assay was carried out in triplicate. The hydrolyze of substrate generate compounds containing sulfhydryl groups that reacts with the Ellman's reagent whose concentration can be colorimetric evaluated at $405 \mathrm{~nm}$ (Trevisan and Macedo 2003). Thus, the absorbance was measured every $60 \mathrm{~s}$ by eight times using an Elisa Thermoplate microplate reader. After addition of $25 \mu \mathrm{L}$ of AChE solution $(0.226 \mathrm{U} / \mathrm{mL}$ in buffer $\mathrm{B})$, the absorbance was again read every $60 \mathrm{~s}$, for ten times. The increase in absorbance was corrected by reaction rate variation before and after addition of the enzyme. The inhibition percentage was calculated by comparing the rates of the sample with the blank.

\section{MTT Cell viability assay}

Lines of normal and tumor cells were used to evaluate the effects of $P$. viridis extracts upon cell proliferation. The normal cells lines chosen BHK21 (Baby Hamster Kidney Fibroblast Cells) and CHO (Chinese hamster ovary cell) were gifts from the Pan-American FMD Center, Rio de Janeiro, Brazil. The tumor cells lines used were B16F10 (murine melanoma) was a gift from the "Instituto Ludwig de Pesquisa sobre o Câncer" (Sao Paulo, Brazil) and 4T1 (murine tumor mammary gland) (American Type Culture Collection, Manasssas, VA). Originally, B16F10 were isolated clones from spontaneous malignant melanoma (Fidler and Kripke 1977), while 4T1 is a thioguanine resistant variant that was obtained from 410.4 without mutagenic exposure (Aslakson and Miller 1992). Both of tumor cells types are able to form a tumor mass and metastazise to lung tissue, once injected in mice.
Firstly, cells were cultured in RPMI 1640 medium (GIBCO, Carlsbad, CA, USA) supplemented with $10 \%$ of heat-inactivated fetal bovine serum (FBS) (GIBCO), 1\% penicillin/ streptomycin (Sigma-Aldrich, St. Louis, $\mathrm{MO})$ at $37^{\circ} \mathrm{C}$ in a humidified atmosphere of $5 \% \mathrm{CO}_{2}$. Once confluent, the monolayer was harvested by incubation with trypsin/EDTA; ethylenediaminetetraacetic acid $(0.025 \%$ and 0.02 $\mathrm{w} / \mathrm{v}$, respectively). The released cell suspension ( $>90 \%$ of viability) were adjusted to the appropriate cell density and then seeded in 96-polystyrene-well plates. In the next day, the cells were exposed for 72 hours to increase concentrations of $P$. viridis extracts or DMT $(20-400 \mu \mathrm{g} / \mathrm{mL})$. Control cells were exposed to RPMI 1640 supplemented with 10 $\%$ of FBS added to $0.2 \%(\mathrm{v} / \mathrm{v})$ DMSO (extracts and DMT vehicle).

Cell viability was measured by means of the MTT (3-(4,5)-dimethylthiahiazo(-z-y1)3,5-diphenytetrazoliumromide) method. In this assay, the tetrazolium compound is reduced in the intracellular medium, to formazan by mitochondrial dehydrogenase. The conversion of blue tetrazolium into purple formazan by metabolically active cells indicates the extent of cell viability. Measure cells viability was done by quantification of formazan dye using a colorimetric method (Heo et al. 1990). MTT assay and colorimetric method were used to evaluate the effects of $P$. viridis extracts on cell proliferation. So, after extracts or DMT exposure period, $10 \mu \mathrm{L}$ of $5 \mathrm{mg} / \mathrm{mL}$ MTT (Sigma Chemical Co, St. Louis, MO, USA) was added onto each well and incubated at $37{ }^{\circ} \mathrm{C}$ for $4 \mathrm{~h}$. The cells were then lysed with dimethyl sulfoxide (DMSO) and the absorbance determined at $570 \mathrm{~nm}$ using an ELISA reader. The results were plotted based on percentage of cell death $v s$. concentration $(\mu \mathrm{g} / \mathrm{mL})$ of the sample, using the software GraphPad Prism 5.0. A non-linear regression model (sigmoidal dose-response option) was used to determine the inhibitory concentration IC50 (i.e., 50\% reduction 
in cell viability) for methanol and ethyl acetate extracts upon normal and tumor cells.

\section{RESULTS AND DISCUSSION}

From leaves of $P$. viridis were identified nineteen constituents: a mixture of long chain hydrocarbons (1), 24-methylene-cycloartenol (2) (De Pascual et al. 1987), squalene (3) (Valladao et al. 2010), $\beta$-sitosterol (4), stigmasterol(5)(Goulartetal. 1993), triacylglycerol (6) (Gunstone 1991), nonacosanal (7), nonacosanol (8) (̌̌ezanka and Sigler 2007), hentriacontanoic acid (9), hexadecanoic acid (10), heptadenoic acid (11) (Gunstone 1991), ursolic acid (12), oleanolic acid (13) (Valadares 2009), 1-palmitoylglycerol or monopalmitin (14) (Gunstone 1991), 3-O- $\beta$-D-glucosyl- $\beta$ sitosterol (15) (Silva et al. In press), 3-O- $\beta$-Dglucosyl-stigmasterol (16) (El-Askary 2005), $N, N$ dimethyltryptamine (17), $N$-methyltryptamine (18) [40], 4-methyl-4-epi-quinate (19) (Gunstone 1991) and methyl tetradecanoate (20) (Gunstone 1991). The chemical structures of some constituents isolated from leaves of $P$. viridis are presented in Figure 1.

The compound $\mathbf{1}$ was identified as a mixture of long chain hydrocarbons. The IR spectrum of 1 showed intense absorption bands in the region of 2958 to $2850 \mathrm{~cm}^{-1}, 1474$ to $1464 \mathrm{~cm}^{-1}$ and a double band at $730 \mathrm{~cm}^{-1}$. The observed profile of this spectrum suggested the aliphatic nature of 1 . The ${ }^{1} \mathrm{H}$ NMR spectra of $\mathbf{1}$ showed hydrogen signal at $\delta_{\mathrm{H}} 0.88(\mathrm{t} ; J=6.0 \mathrm{~Hz})$ characteristic of methyl groups of hydrocarbons. The IR spectrum of $\mathbf{2}$ showed intense absorption bands in the region of $3403(\mathrm{OH}), 1640(\mathrm{C}=\mathrm{C})$ and $1047 \mathrm{~cm}^{-1}(\mathrm{CO})$. The ${ }^{1} \mathrm{H}$ NMR spectra of 2 showed hydrogen signal at $\delta_{\mathrm{H}} 0.35(\mathrm{~d} ; J=4.17 \mathrm{~Hz})$ and $\delta_{\mathrm{H}} 0.57(\mathrm{~d} ; J=4.11$ $\mathrm{Hz}$ ) indicating a cyclopropane ring. The ${ }^{13} \mathrm{C} \mathrm{NMR}$ data compared with the literature confirmed the compound 2 as 24-methylene-cycloartenol (De Pascual et al. 1987). The ${ }^{1} \mathrm{H}$ and ${ }^{13} \mathrm{C}$ NMR spectra
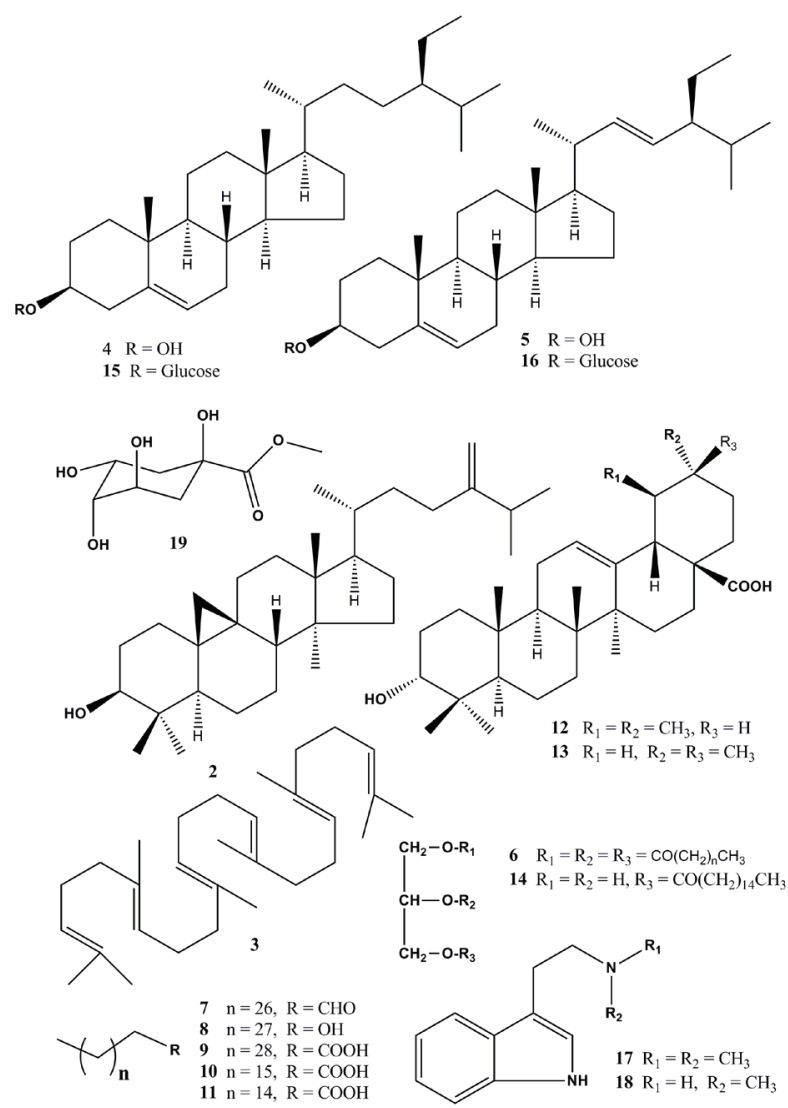

Figure 1 - Chemical structures of some constituents isolated from leaves of $P$. viridis.

of compound 3 showed signals at $\delta_{\mathrm{H}} 5.08-5.15$ and $\delta_{\mathrm{C}}$ 124.31-135.12 that are characteristics of olefin compounds. The ${ }^{13} \mathrm{C}$ NMR data compared with the literature confirmed the compound $\mathbf{3}$ as squalene (Valladao et al. 2010). In the ${ }^{1} \mathrm{H}$ NMR spectrum of compounds $4,5,15$ and 16 were observed the signal at $\delta_{\mathrm{H}}$ 5.2-5.3 attributed to olefin hydrogen, and a multiplet at $\delta_{\mathrm{H}} 3.4-3.5$ correspondents to hydroxylated carbon. The profile of these spectra was similar to those observed for the steroidal skeletons. In the spectra of compound $\mathbf{1 5}$ and $\mathbf{1 6}$ were observed signals at $\delta_{\mathrm{H}} 3.60-4.58$ that are characteristics of glucose hydrogen. The chemical shift assignments of signals observed in the ${ }^{13} \mathrm{C}$ NMR spectra, mainly the signals around $\delta_{C} 121.72$ and $\delta_{\mathrm{C}} 140.78$, and $\delta_{\mathrm{C}} 129.30$ and $\delta_{\mathrm{C}} 138.31$ (15 and 16 , respectively) were attributed to olefin carbons. The presence of signals at $\delta_{\mathrm{C}} 102.01-102.4$ in ${ }^{13} \mathrm{C}$ 
NMR spectra confirmed compounds $\mathbf{1 5}$ and $\mathbf{1 6}$ as glucosylated steroids. The ${ }^{13} \mathrm{C}$ NMR data compared with the literature confirmed compound 4 as $\beta$-sitosterol, 5 as stigmasterol (Goulart et al. 1993), 15 as 3-O- $\beta$-D-glucosyl- $\beta$-sitosterol (Silva et al. 2016 ), and 16 as 3-O- $\beta$-D-glucosyl-stigmasterol (El Askary 2005).

The IR spectrum of $\mathbf{6}$ showed intense absorption bands in the region of 2928-2856 (CH), 1742 and $1720(\mathrm{C}=\mathrm{O})$, and $1170 \mathrm{~cm}^{-1}(\mathrm{CO})$. The absorption bands at 1742, 1720, and $1170 \mathrm{~cm}^{-1}$ indicate an ester group. The signals at $\delta_{\mathrm{C}} 173.21$ and $\delta_{\mathrm{C}} 171.97$ observed in ${ }^{13} \mathrm{C}$ NMR spectra were attributed to carbonyl groups. The ${ }^{13} \mathrm{C}$ NMR data compared with the literature confirmed compound 6 as triacylglycerol (Gunstone 1991). In the IR spectra of $\mathbf{7}$ and $\mathbf{8}$ were observed intense absorption bands in the region of 3346 ( $\mathrm{OH}$ for compound 8), 2918-2915 (CH), $1720(\mathrm{C}=\mathrm{O}$ for 7), and 720-730 $\mathrm{cm}^{-1}$ (long chain). The absorption bands in the regions of $3346 \mathrm{~cm}^{-1}$ indicated 8 as an alcohol, and at $1720 \mathrm{~cm}^{-1}$ indicated 7 as an aldehyde. The ${ }^{1} \mathrm{H}$ NMR and ${ }^{13} \mathrm{C}$ spectra of compound 7 showed signals at $\delta_{\mathrm{H}} 9.7(\mathrm{t} ; J=1.6 \mathrm{~Hz})$ and at $\delta_{\mathrm{C}} 202.85$ which are characteristics of aldehyde. The spectral data compared with the literature confirmed compound 7 as being nonacosanal (rezanka and Sigler 2007). The ${ }^{1} \mathrm{H}$ and ${ }^{13} \mathrm{C}$ NMR spectra of compound 8 showed signals at $\delta_{\mathrm{H}} 3.66(\mathrm{t} ; J=$ $6.5 \mathrm{~Hz}$ ) and $\delta_{\mathrm{C}} 63.11$ that are characteristics of alcohol. The spectral data confirmed the compound $\mathbf{8}$ as nonacosanol. For compounds $\mathbf{9 ,} \mathbf{1 0}$ and $\mathbf{1 1}$ were observed signals at $\delta_{\mathrm{H}} 0.88(\mathrm{t} ; J=6.3 \mathrm{~Hz})$ correspondent to methyl groups, and at $\delta_{\mathrm{H}} 1.60$ 1.73 and $\delta_{\mathrm{H}} 2.35(\mathrm{t} ; J=7.4 \mathrm{~Hz})$ that are typical of carbon $\beta$ and $\alpha$ from carboxylic acid, respectively. The presence of signals at $\delta_{\mathrm{C}}$ 14.12-14.13 (methyl group) and at $\delta_{\mathrm{C}} 176.50-177.90$ (carboxyl group) contributed to identification of these compounds as carboxylic acids (Gunstone 1991). The spectral data confirmed compound $\mathbf{9 ,} \mathbf{1 0}$ and $\mathbf{1 1}$ as hentriacontanoic, hexadecanoic and heptadenoic acids respectively. In the ${ }^{1} \mathrm{H}$ NMR spectra of compound 12 and 13 were observed signals at $\delta_{\mathrm{H}}$ 0.70-2.05 which are characteristics of triterpenes, and the signals at $\delta_{\mathrm{H}} 5.25-5.28(\mathrm{t} ; J=3.8 \mathrm{~Hz})$, that are attributed to hydrogen atoms of double bound commonly found in ursane and oleanane skeleton. The signals at $\delta_{\mathrm{C}} 16.93$ and $\delta_{\mathrm{C}} 21.17$ confirmed the structure of ursane triterpene for $\mathbf{1 2}$, and at $\delta_{\mathrm{C}} 33.07$ and $\delta_{\mathrm{C}} 23.63$ the structure of oleanane triterpene for 13. The ${ }^{13} \mathrm{C}$ NMR data compared with the literature confirmed compounds $\mathbf{1 2}$ as ursolic acid, and $\mathbf{1 3}$ as oleanolic acid (Valadares 2009). In the IR spectrum of 14 were observed intense absorption bands at $3472(\mathrm{OH}), 2928-2852(\mathrm{CH}), 1742(\mathrm{C}=\mathrm{O})$, and at $722 \mathrm{~cm}^{-1}$ (long chain). In the ${ }^{1} \mathrm{H}$ NMR spectra of compound 14 the signals at $\delta_{\mathrm{H}} 4,13-4,17$ (dd; $J=11,6$ and $6,1 \mathrm{~Hz})$ and 4,19-4,23 (dd; $J=11,6$ and $4,6 \mathrm{~Hz}$ ) were attributed to hydrogen atoms of hydroxylated carbon $(\mathrm{C} 1)$. In the ${ }^{13} \mathrm{C}$ NMR spectra of constituent 14, were attributed the signals at $\delta_{\mathrm{C}} 174.37$ to carbonyl from ester, and at $\delta_{\mathrm{C}} 65.19$ and 63.36 to hydroxylated carbon atom. The ${ }^{13} \mathrm{C}$ NMR data compared with the literature confirmed compound $\mathbf{1 4}$ as 1-palmitoylglycerol (Goulart et al. 1993). The absorption band at $3500-3400 \mathrm{~cm}^{-1}$ observed in the IR spectra of $\mathbf{1 7}$ and $\mathbf{1 8}$ indicate the presence of $\mathrm{NH}$ from indole ring and these compounds as being alkaloids. The ${ }^{1} \mathrm{H}$ NMR and ${ }^{13} \mathrm{C}$ spectra of compound $\mathbf{1 7}$ showed signals at $\delta_{\mathrm{H}} 6.92-7.09, \delta_{\mathrm{H}} 7.29(\mathrm{~d} ; J=8.0 \mathrm{~Hz})$ and 7.49 $\left(\mathrm{d} ; J=8.0 \mathrm{~Hz}\right.$ ), and $\delta_{\mathrm{C}} 112.25$ and 138.15 which are characteristic of indole ring. The molecular formula of $\mathbf{1 7}$ was established as $\mathrm{C}_{12} \mathrm{H}_{16} \mathrm{~N}_{2}$ on the basis of the molecular ion at $\mathrm{m} / \mathrm{z} 189.1359[\mathrm{M}+\mathrm{H}]$ (calcd 189.1386) obtained in the LC/MS-TOF. The spectral data compared with the literature confirmed compound $\mathbf{1 7}$ as being the N,N-dimethyltryptamine (Gaujac et al. 2013). By means of LCMS-ESIIT-TOF data, the compound $\mathbf{1 8}$ was identified as $\mathrm{N}$-methyltryptamine. Based on the molecular ion at $\mathrm{m} / \mathrm{z} 175.1214[\mathrm{M}+\mathrm{H}]$, the molecular formula of 18 was determined as $\mathrm{C}_{11} \mathrm{H}_{14} \mathrm{~N}_{2}$ (calcd 175.1229). 
The IR spectrum of 19 showed absorption bands at 3446, 3408 and 3366, $\mathrm{cm}^{-1}(\mathrm{OH}), 2924,2958 \mathrm{~cm}^{-}$ 1,1436 and $1370 \mathrm{~cm}^{-1}(\mathrm{CH}), 1144 \mathrm{~cm}^{-1}$ and $1118-$ $1078 \mathrm{~cm}^{-1}$ (C-O). The absorption band at $1736 \mathrm{~cm}^{-1}$ indicates an ester group. In the ${ }^{1} \mathrm{H}$ NMR spectrum of 19 were observed the signals at $\delta_{\mathrm{H}} 1.66-1.71(\mathrm{dd}$, $1 \mathrm{H}, \mathrm{H} 2 \mathrm{eq}, J=13.7$ and $5.1 \mathrm{~Hz}$ ) and at $\delta_{\mathrm{H}} 1.81-1,85$ (dd, $1 \mathrm{H}, \mathrm{H6eq}, J=13.4$ and $2.9 \mathrm{~Hz}$ ) and a multiplet at $\delta_{\mathrm{H}}$ 2.28-2.37, attributed to hydrogen H6ax and $\mathrm{H} 2 \mathrm{ax}$, a signal at $\delta_{\mathrm{H}} 3.72-3.75(\mathrm{dd}, 1 \mathrm{H}, J=5,7$ and $3.0 \mathrm{~Hz}$ ), associated to $\mathrm{H} 4$, a simplet at $\delta_{\mathrm{H}} 3.77$ correspondent to hydrogen atoms of methoxyl. The multiplet at $\delta_{\mathrm{H}} 4.01-4.05(1 \mathrm{H})$ was correlated to $\mathrm{H} 3$ and at $\delta_{\mathrm{H}} 4.12-4.16(1 \mathrm{H})$ and attributed to $\mathrm{H} 5$. Based on the ${ }^{13} \mathrm{C}$ NMR spectra including DEPT135 data were classified $3 \mathrm{CH}, 2 \mathrm{CH}_{2}, 1 \mathrm{CH}_{3}$ and 2 non-hydrogenated carbon atoms, one being $\mathrm{C}=\mathrm{O}\left(\delta_{\mathrm{H}}\right.$ 176.12). The ${ }^{1} \mathrm{H}$ and ${ }^{13} \mathrm{C}$ NMR chemical shift assignments of $\mathbf{1 9}$ were in accordance to the data previously published for 4-metil-epi-quinate (Armesto et al. 2006). Through the LCMSESI-IT-TOF the molecular formula of $\mathbf{1 9}$ was confirmed based on the ion of $\mathrm{m} / \mathrm{z} 229.0687 \mathrm{Da}$ (calcld. 229.0688). The IR spectrum of $\mathbf{2 0}$ showed intense absorption bands at 2926-2854 (CH), 1744 $(\mathrm{C}=\mathrm{O})$, and $722 \mathrm{~cm}^{-1}$ (carbon long chain). In the ${ }^{1} \mathrm{H}$ NMR spectra of compound 20 were observed signals at $\delta_{\mathrm{H}} 3.67$ characteristic of hydrogen atoms of methoxyl groups, at $\delta_{\mathrm{H}} 2.30(\mathrm{t} ; J=7.5 \mathrm{~Hz})$ attributed to hydrogen atoms linked to $\alpha$ carbon atom, and a multiplet at $\delta_{\mathrm{H}} 1.54-1.65$ attributed to hydrogen atoms linked to $\beta$ carbon atom. In the ${ }^{13} \mathrm{C}$ NMR spectra of 20 were observed signals at $\delta_{\mathrm{C}}$ 174.43 attributed to carbonyl from ester, $\delta_{\mathrm{C}} 51.46$ attributed to carbon atom from methoxyl group, and $\delta_{\mathrm{C}} 14.13$ characteristic of methyl group. The ${ }^{13} \mathrm{C}$ NMR data compared with the literature confirmed compound $\mathbf{2 0}$ as methyl tetradecanoate (Gunstone 1991). The compounds $\mathbf{1}$ to 20 isolated from leaves of $P$. viridis were respectively identified by means of melting point, spectral data from IR, NMR and MS and comparison with the published data.
TABLE I

Percent inhibition of acetylcholinesterase (AChE) induced by substances isolated from leaves of $P$. viridis.

\begin{tabular}{|c|c|c|}
\hline Sample & $\begin{array}{l}\text { Inhibition }{ }^{\mathrm{a}} \text { of } \mathrm{AChE} \\
(\% \pm \mathrm{sd})\end{array}$ & $\begin{array}{l}\text { Coefficient } \\
\text { of variation }\end{array}$ \\
\hline Hexane extract & $80.34 \pm 1.33$ & 0.017 \\
\hline Chloroform extract & $91.76 \pm 2.25$ & 0.025 \\
\hline Ethyl acetate extract & $91.21 \pm 3.95$ & 0.043 \\
\hline Methanol extract & $85.28 \pm 2.99$ & 0.035 \\
\hline Cycloartenol & $49.53 \pm 3.37$ & 0.068 \\
\hline DMT & $19.84 \pm 4.83$ & 0.244 \\
\hline $\begin{array}{l}\beta \text {-sitosterol and } \\
\text { stigmasterol }\end{array}$ & $67.15 \pm 4.85$ & 0.072 \\
\hline $\begin{array}{l}\text { Galantamine } \\
\text { (Standard) }\end{array}$ & $90.31 \pm 0.45$ & 0.005 \\
\hline Eserine (Standard) & $70.14 \pm 0.85$ & 0.012 \\
\hline
\end{tabular}

The hexane (EHF), chloroform (ECF), ethyl acetate $(\mathrm{EAcF})$, and methanol (EMeF) extracts and some substances isolated from leaves of $P$. viridis were subjected to the following biological assays: acetylcholinesterase inhibition activity and on the viability of normal and tumor cells line.

The hexane, chloroform, ethyl acetate and methanol extracts and the constituents cycloartenol (2), DMT (17) and a mixture of $\beta$-sitosterol (4) and stigmasterol (5) isolated from the leaves of $P$. viridis present significant acetylcholinesterase inhibition properties, wherein the chloroform and ethyl acetate extracts induced inhibition effect above 90\% (Table I).

In accordance with Trevisan and Macedo (2003) extracts whose enzyme inhibition is greater than or equal to $50 \%$ are considered as promising candidates for future drugs. Thus, the results open perspectives for the isolation of the most active compounds from $P$. viridis, which may be considered as templates to obtain drug candidate compounds to be tested against the Alzheimer disease. 

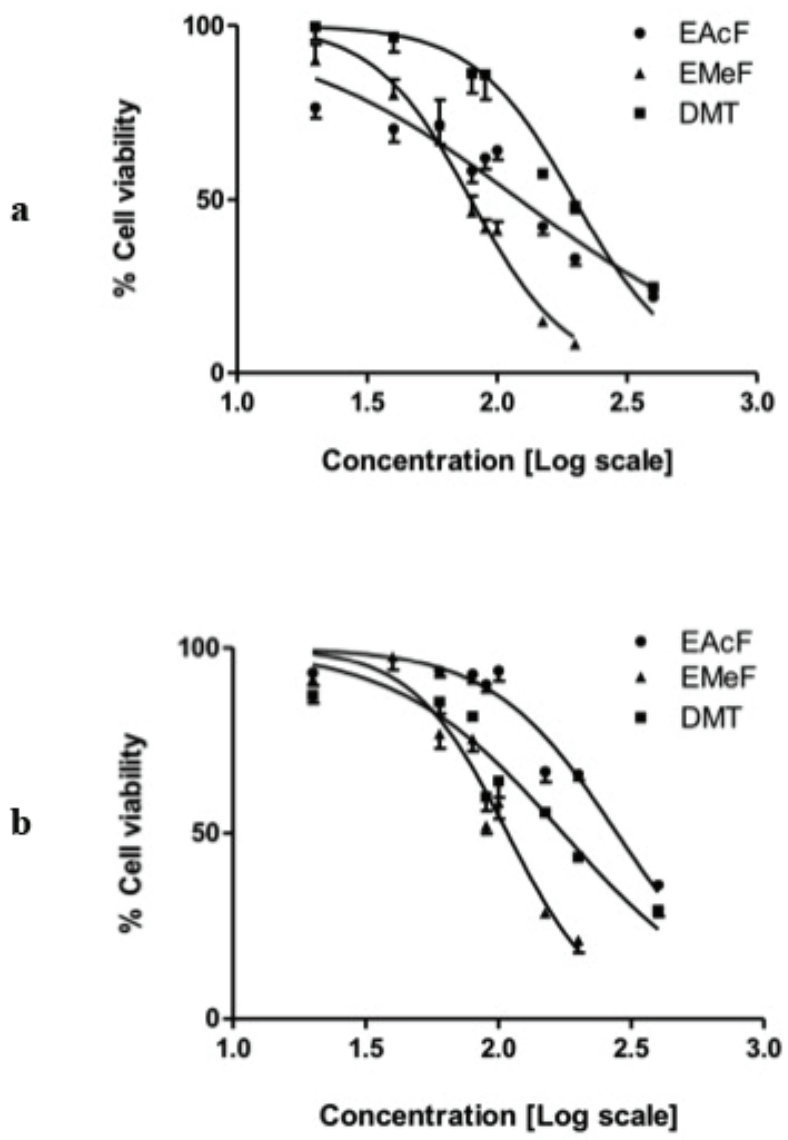

Figure 2 - Representative curves of surviving B16F10 (A) and 4T1 cells (B) versus log of concentration $(\mu \mathrm{g} / \mathrm{mL})$ of $\mathrm{EAcF}$, EMeFand DMT, isolated from leaves of $P$. viridis. The IC50 value was evaluated by means of non-linear regression $(n=5)$.

By means of the IC50 of the extracts upon B16F10 and 4T1 tumor cells was possible to conclude that at lower concentrations EMeF induce an incidence of cytotoxic effect higher than EAcF, for both cell strains (Figure 2). EMeF was also considered more cytotoxic than DMT that is the principal constituent in the methanol extract from leaves of $P$. viridis. It is possible to infer that the cytotoxicity on tumor cells promoted by EMeF involves the action of other chemical constituents than the DMT.

Both ethyl acetate and methanol extracts showed the property to reduce tumor cell viability
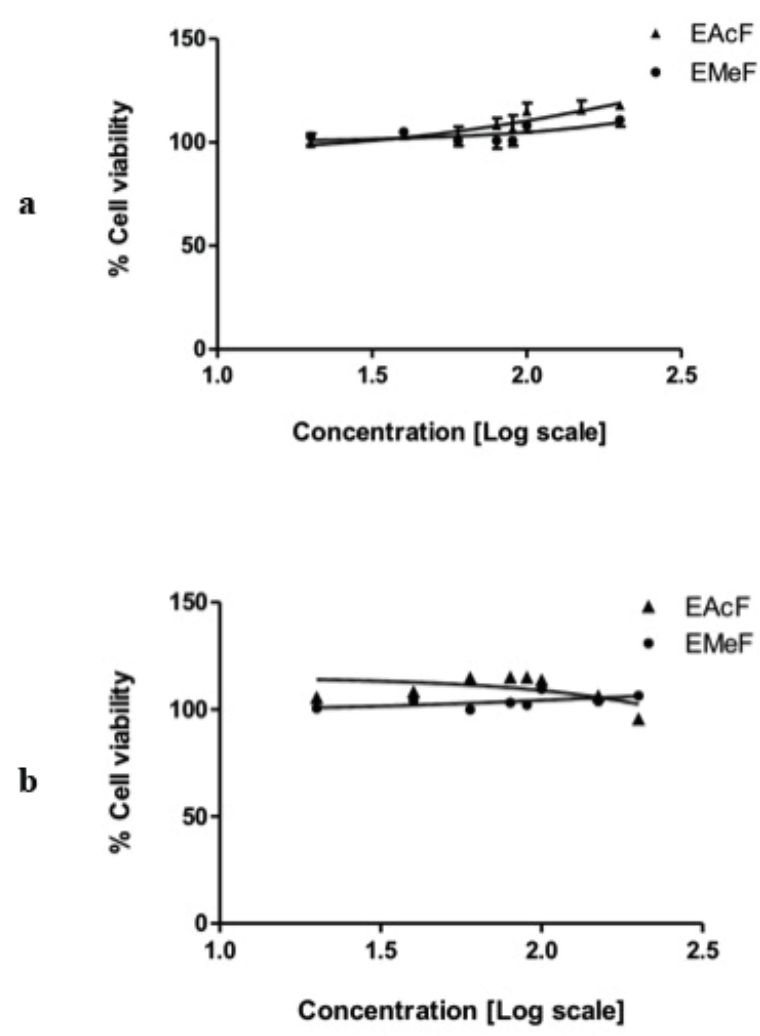

Figure 3 - Representative curves of surviving BHK-21 (A) and CHO cells (B) versus log of concentration $(\mu \mathrm{g} / \mathrm{mL})$ of $\mathrm{EAcF}$ and $\mathrm{EMeF}$ extracts from leaves of $P$. viridis. The IC50 value was not determined in the concentration range used $(n=5)$.

(B16F10 and 4T1), although do not interfere in viability of normal cells (BHK-21 and $\mathrm{CHO}$ ). The non-cytotoxicity on normal cell strains used as reference shows a selectivity action of extracts from leaves of $P$. viridis. This selective cytotoxic effect is an important property to be achieved in antitumor new drugs. The present study constitutes perspectives for the investigations about how these compounds act in viability reduction of B16F10 and 4T1 tumor cells.

\section{ACKNOWLEDGMENTS}

The authors thank the Fundação de Amparo à Pesquisa do Estado de Minas Gerais (FAPEMIG) for financial support and Conselho Nacional de Desenvolvimento Científico e Tecnológico (CNPq) 
for studentship (DBSS). The authors are also thankful to Núcleo de Lagoa Dourada of União do Vegetal for providing $P$. Viridis sample.

\section{REFERENCES}

ALMEIDA MZ. 2011. Plantas medicinais. $3^{\mathrm{a}}$ ed., Salvador: EDUFBA, $221 \mathrm{p}$.

ARANHA C, TRAVAINE G AND CORREA MA. 1991. Aspectos botânicos e taxonômicos das plantas Banisteriopsis sp e Psychotria sp. $1^{\circ}$ Congresso em Saúde. Centro de Estudos Médicos - UDV, São Paulo.

ARMESTO N, FERNÁNDEZ S, FERRERO M AND GOTOR V. 2006. Influence of intramolecular hydrogen bonds in the enzyme-catalyzed region selective acylation of quinic and shikimic acid derivatives. Tetrahedron: 62: 5401-5410.

ASLAKSON CJ AND MILLER FR. 1992. Selective events in the metastatic process defined by analysis of the sequential dissemination of subpopulations of a mouse mammary tumor. Cancer Res 52: 1399-1405.

BLACKLEDGE RD AND TAYLOR CM. 2003. Psychotria viridis - A Botanical Source of dimethyltryptamine (DMT). Microgram J 1: 18-22.

BREAKEFIELD XO, CASTIGLIONE CM AND EDELSTEIN SB. 1976. Monoamine oxidase activity decreased in cells lacking hypoxanthine phosphoribosyltransferase activity. Science 192: 10181020.

CALLAWAY JC, AIRAKSINEN MM, MCKENNA DJ.BRITO CS AND GROB CS. 1994. Platelet serotonin uptake sites increased in drinkers of ayahuasca. Psychopharmacol 116: 385-387.

CALLAWAY JC AND GROB CS. 1998. Ayahuasca preparations and serotonin reuptake inhibitors: a potential combination for severe adverse interactions. J Psychoactive Drugs 30: 367-369.

CAMARGO MTLA. 2006. Os poderes das plantas sagradas numa abordagem etnofarmacobotânica. Rev Mus Arqueol Etnol 16: 395-410.

CAMARGO MTLA. 2007. Amansa-senhor: a arma dos escravos contra seus senhores. Rev Pós Ci Soc 4: 31-42.

CHAN-BLANCO Y, VAILLAN F, PEREZ AM, REYNES M, BRILLOUET J AND BRAT P. 2006. The noni fruit (Morinda citrifolia L.): A review of agricultural research, nutritional and therapeutic properties. J Food Compos Anal 19: 645-654.

CORDELL GA，QUINN-BEATTIE ML AND FARNSWORTH NR. 2001. The potential of alkaloids in drug discovery. Phytother Res 15: 183-205.

CORRÊA AD, SIQUEIRA-BATISTA R AND QUINTAS LE. 1998. Plantas Medicinais do Cultivo à terapêutica. Petrópolis: Ed. Vozes, 246 p.
DE PASCUAL T, URONES JG, MARCOS IS, BASABE P, SEXMERO M AND FERNÁNDEZ R. 1987. Triterpenes from Euphorbia broteri. J Phytochem 26: 1767-1776.

DELPRETE PG AND JARDIM JG. 2012. Systematics, taxonomy and floristics of Brazilian Rubiaceae: an overview about the current status and future challenges. Rodriguésia 63: 101-128.

DUNSTAN CA, NOREEN Y, SERRANO G, COX PA, PERERA P AND BOHLIN L. 1997. Evaluation of some Samoan and Peruvian medicinal plants by prostaglandin biosynthesis and rat ear oedema assay. J Ethnopharmacol 57: $35-56$

EL-ASKARY HI. 2005. Terpenoids from Cleomedro serifolia (Forssk.) Del. Molecules 10: 971-977.

FARIA EO. 2009. Estudo Fitoquímico das folhas da Espécie Psychotria prunifolia (Kunth) Steyerm (Rubiaceae). Dissertação de Mestrado. Instituto de Química. Universidade Federal de Goiás. Goiania, GO. (Unpublished).

FARZIN D AND MANSOURI N. 2006. Antidepressant-like effect of harmane and other $\beta$-carbolines in the mouse forced swim test. Eur Neuropsychopharmacol 16: 324328.

FIDLER IJ AND KRIPKE ML. 1977. Metastasis results from preexisting variant cells within a malignant tumor. Science 197: 893-895.

FORTUNATO JJ. 2009. Efeitos comportamentais e neuroquímicos da harmina em modelos animais de depressão, Tese Doutorado. Departamento de Bioquímica. Universidade Federal do Rio Grande do Sul. Porto Alegre RS.

GARRIDO RG AND SABINO BD. 2009. Ayahuasca: entre o legal e o cultural. Saúde Ética \& Justiça 14: 44-53.

GAUJAC A, MARTINEZ ST, GOMES AA, ANDRADE SJ, PINTO AC, DAVID JM, NAVICKIENE S AND ANDRADE JB. 2013. Application of analytical methods for the structural characterization and purity assessment of N,N-dimethyltryptamine, a potent psychedelic agent isolated from Mimosa tenuiflora inner barks. Microchem J 109: 78-83.

GOULART MOF, SANT'ANA AEG, LIMA RA AND CAVALCANTE SH. 1993. Fitoconstituintes químicos isolados de Jatropha elliptica. Atribuição dos deslocamentos químicos dos átomos de carbono e hidrogênio dos diterpenos jatrofolonas A e B. Quim Nova 16: 95-100.

GROISMAN A. 2013. Saúde, risco e uso religioso em disputas pelo status legal do uso da ayahuasca: implicações e desdobramentos de processos judiciais ocorridos nos Estados Unidos. Antropologia em Primeira Mão 139: 5-19.

GUNSTONE FD. 1991. ${ }^{13} \mathrm{C}-\mathrm{NMR}$ studies of mono-, di- and triacylglycerols leading to qualitative and semiquantitative 
information about mixtures of these glycerol esters. Chem Phys Lip 58: 219-224.

HEO DS, PARK JG, HATA K, DAY R, HERBERMAN RB AND WHITESIDE TL. 1990. Evaluation of tetrazoliumbased semiautomatic colorimetric assay for measurement of human antitumor cytotoxicity. Cancer Res 50: 36813690 .

KHAN MR, KIHARA M AND OMOLOSO AD. 2001. Antimicrobial activity of Psychotria microlabastra. Fitoterapia 72: 818-821.

LABATE BC. 2011. Paradoxes of ayahuasca expansion: The UDV-DEA agreement and limits of freedom of religion. Informa Healthcare: 1-8.

LIBOT F, MIET C, KUNESH N AND POISSON JE. 1987. Rubiacées d'Océanie: alcaloïdes de Psychotria oleoides de Nouvelle-Calédonie et de Calicodendron milnei du Vanuatu (Nouvelles-Hébrides). J Nat Prod 50: 468-473.

LIMA LB. 2011. Triagem da atividade antioxidante e anticolinesterásica de extratos naturais: seleção e estudo químico biomonitorado de Streptomyces sp. e de Psychotria carthagenensis. Dissertação de Mestrado. Faculdade de Filosofia, Ciências e Letras de Ribeirão Preto. Universidade de São Paulo. Ribeirão Preto SP. (Unpublished).

LOCHER CP, BURCH MT, MOWER HF, BERESTECKY J, DAVIS H, VAN POEL B, LASURE A, BERGHE DAV AND VLIETINCK AJ. 1995. Anti-microbial activity and anti-complement activity of extracts obtained from selected Hawaiian medicinal plants. J Ethnopharmacol 49: 23-32.

LUNA LE. 1986. Shamanism among the mestizo population of the Peruvian Amazon. J Ethnopharmacol 11: 123-133.

MATOS FJA. 1988. Introdução à Fitoquímica Experimental. Fortaleza: UFC, $129 \mathrm{p}$.

MORAES AP. 2013. Alcaloides indólicos das partes aéreas de Psychotria sp. (Rubiaceae) e síntese de tiohidantoínas e tioureias derivadas de aminoácidos e do R-(+)-limoneno. Dissertação de Mestrado. Instituto de Química. Universidade Federal de Goiás. Goiânia GO. (Unpublished).

NEPOKROEFF M, BREMER B AND SYSTMA KJ. 1999. Reorganization of the genus Psychotria and tribe Psychotrieae (Rubiaceae) inferred from ITS and rbcL sequence Data. Syst Bot 24: 5-27.

NODARI RO AND GUERRA MP. 1999. Biodiversidade: aspectos biológicos, geográficos, legais e éticos. In:
SIMÕES CMO (Ed), Farmacognosia da planta ao medicamento. Porto Alegre: UFRGS/UFSC, p. 11-24.

PIRES APS, OLIVEIRA CDR AND YONAMINE M. 2010. Ayahuasca: uma revisão dos aspectos farmacológicos e toxicológicos. Rev Ciên Farm Básica Apl 31: 15-23.

ŘEZANKA T AND SIGLER K. 2007. Identification of very long chain unsaturated fatty acids from Ximenia oil by atmospheric pressure chemical ionization liquid chromatography-mass spectroscopy. Phytochemistry 68: 925-934.

RHEE IK, VAN-DE-MEENT M, INGKANINAN K AND VERPOORTE R. 2001. Screening for acetylcholinesterase inhibitors from Amaryllidaceae using silica gel thin-layer chromatography in combination with bioactivity staining. J Chromatogr 915: 217-223.

SILVA FC ET AL. In Press. Antidiarrheal activity of extracts from Maytenus gonoclada and inhibition of Dengue virus by lupeol. An Acad Bras Cienc.

STEYERMARK JA. 1974. Rubiaceae. p. 1-2070. In: Lasser T (Ed), Flora de Venezuela 9(1-3). Instituto Botánico, Dirección de Recursos Naturales Renovables, Ministerio de Agricultura y Cría, Caracas.

TEIXEIRA DC, QUINTEIRO MMC, BAPTISTA AAAND SILVA JG. 2008. Uso e manejo de plantas ritualísticas na comunidade do santo daime em Galdinópolis, Nova Friburgo, RJ, Brazil. Rev Ci Vida 28: 63-74.

TREVISAN MTS AND MACEDO FVV. 2003. Seleção de plantas com atividade anticolinasterase para tratamento da doença de Alzheimer. Quim Nova 26: 301-304.

VALADARES YM. 2009. Remijia ferruginea D.C., Jacaranda caroba D.C. e Solanum paniculatum L: fitoquímica, atividades biológicas e síntese de derivados dos ácidos ursólico e oleanólico. Tese de doutorado. Faculdade de Farmácia. Universidade Federal de Minas Gerais. Belo Horizonte MG.

VALLADAO FN, MIRANDA RRS, OLIVEIRA GS, SILVA GDF, DUARTE LP AND VIEIRA-FILHO SA. 2010. Constituents of fruit pulp of Maytenus salicifolia and complete 1D/2D NMR data of 3 $\beta$-hydroxy-D:B-friedoolean-5-ene. Chem Nat Comp 46: 686-691.

VEIGA JVF. 2008. Estudo do consumo de plantas medicinais na Região Centro-Norte do Estado do Rio de Janeiro: aceitação pelos profissionais de saúde e modo de uso pela população. Braz J Pharmacogn 18: 308-313.

WAGNER H AND BLADT S. 1996. A Thin Layer Chromatography Atlas, $2^{\text {nd }}$ ed., Dordrecht: Springer, 384 p. 